\title{
Survival COVID-19 in Adult Patients with Liver Cirrhosis
}

\author{
Gita Aprilicia*,**, Syahrizal Syarif*, Kemal Fariz Kalista**, Andri Sanityoso \\ Sulaiman **, Irsan Hasan**, Cosmas Rinaldi A. Lesmana**, Juferdy Kurniawan**, \\ Chyntia Olivia Maurine Jasirwan**, Saut Horas Hatoguan Nababan**, \\ Rino Alvani Gani** \\ *Department of Epidemiology, Faculty of Public Health, Universitas Indonesia, Depok \\ ${ }^{* *}$ Division of Hepatobiliary, Department of Internal Medicine,
} Faculty of Medicine Universitas Indonesia/Dr. Cipto Mangunkusumo National General Hospital, Jakarta

\begin{abstract}
Corresponding author:
Kemal Fariz Kalista. Division of Hepatobiliary. Department of Internal Medicine, Dr. Cipto Mangunkusumo General National Hospital. Jl. Diponegoro No. 71 Jakarta Indonesia. Phone: +62-21-31900924; facsimile: +6221-3918842.E-mail: kemalfarizkalista@yahoo.com
\end{abstract}

\section{ABSTRACT}

Background: Coronavirus disease-2019 (COVID-19) is a disease caused by infection of SARS-CoV-2 virus which leads to mortality due to respiratory failure. The progression of COVID-19 is more severe in patients with pre-existence morbidities, including liver disease. Recently, a few studie showed that liver cirrhosis patients with COVID-19 had a higher risk of mortality rather than liver cirrhosis patients without COVID-19 infection. Nevertheless, the study of survival COVID-19 in a patient with underlying liver cirrhosis is still limited. The aim of this study is to evaluate the survival of COVID-19 in adult patients with liver cirrhosis

Method: An observational study in Cipto Mangunkusumo Hospital was conducted. Patients with underlying liver cirrhosis between March 2020-January 2021 with positive confirmation of COVID-19 were enrolled in this study. Liver cirrhosis patients without COVID-19 were enrolled as a comparison. Both liver cirrhosis patients with and without COVID-19 were follow up at the time of hospital admission until 30 days outcome. Kaplan Meier and a log-rank test were conducted to evaluate the comparison of survival rate in liver cirrhosis patients with and without COVID-19. Multivariate Cox Proportional Hazard was conducted to identify the independent risk factors related to survival.

Results: There were 22 liver cirrhosis patients with COVID-19 and 116 liver cirrhosis patients included in this study. Presentation of gender and age similar both of them. Predominantly males with average age were 57 years $\pm 13,60$ for cirrhosis with COVID-19 patients and 53 years $\pm 12,75$ for without COVID-19. The survival rate of liver cirrhosis patients with COVID-19 lower than liver cirrhosis patients without COVID-19 (35.8\% vs. $67.2 \%$, p-value 0.001). Median survival of liver cirrhosis patients with COVID-19 was 4 days (95\% CI: 1-8 days), while median survival of liver cirrhosis patients without COVID-19 couldn't be reached since the survival rate of this group above 50\%. Final model Cox PH showed that liver cirrhosis with COVID-19 (HR: 8.99; CI 95\%: 4.55 - 17.80, p-value 0.001) and Child-Pugh class C (HR: 5.61; 95\% CI: 2.76-11.40, p value 0.001) were the independent risk factors associated with poor survival.

Conclusion: The survival rate of liver cirrhosis patients with COVID-19 lower than liver cirrhosis patients without COVID-19. Liver cirrhosis with COVID-19 and Child-Pugh class C were associated with poor survival.

Keywords: COVID-19, liver cirrhosis, survival rate 


\section{ABSTRAK}

Latar belakang: Coronavirus disease-2019 (COVID-19) merupakan penyakit infeksi virus SARS-CoV-2 yang dapat menyebabkan kematian akibat adanya gagal napas. Perkembangan COVID-19 akan lebih parah pada pasien dengan adanya co-morbiditas penyerta, termasuk penyakit hati. Dalam waktu terkini, beberapa penelitian menunjukkan bahwa pasien sirosis hati dengan COVID-19 memiliki risiko kematian yang lebih tinggi daripada pasien sirosis hati tanpa infeksi COVID-19. Meski demikian, studi terhadap ketahanan hidup COVID-19 pada pasien dengan sirosis hati masih terbatas. Tujuan penelitian ini adalah untuk mengevaluasi kelangsungan hidup COVID-19 pada pasien dewasa dengan sirosis hati.

Metode: Penelitian ini merupakan studi observasional di RSUD Cipto Mangunkusumo. Pasien dengan sirosis hati dengan konfirmasi positif COVID-19 pada periode Maret 2020-Januari 2021 dikumpulkan dalam penelitian ini. Pasien sirosis hati tanpa COVID-19 dikumpulkan sebagai pembanding. Baik pasien sirosis hati dengan maupun tanpa COVID-19 dilakukan pengamatan pada saat masuk rumah sakit hingga 30 hari. Kaplan Meier dan uji log rank dilakukan untuk mengevaluasi perbandingan tingkat kelangsungan hidup pada pasien sirosis hati dengan dan tanpa COVID-19. Analisis multivariat Cox Proportional Hazard dilakukan untuk mengidentifikasi faktor risiko independen yang berhubungan dengan kelangsungan hidup pasien sirosis hati.

Hasil: Terdapat 22 pasien sirosis hati dengan COVID-19 dan 116 pasien sirosis hati tanpa COVID-19 dalam penelitian ini. Presentase jenis kelamin dan usia keduanya setara. Sebagian besar laki-laki dengan usia ratarata 57 tahun \pm 13,60 untuk pasien sirosis dengan COVID-19 dan 53 tahun $\pm 12,75$ untuk pasien sirosis tanpa COVID-19. Tingkat kelangsungan hidup pasien sirosis hati dengan COVID-19 lebih rendah daripada pasien sirosis hati tanpa COVID-19 (35,8\% vs. 67,2\%, nilai p 0,001). Median kelangsungan hidup penderita sirosis hati dengan COVID-19 adalah 4 hari (95\% CI: 1-8 hari), sedangkan median kelangsungan hidup penderita sirosis hati tanpa COVID-19 tidak dapat dicapai karena tingkat kelangsungan hidup kelompok ini di atas 50\%. Model akhir Cox PH menunjukkan bahwa sirosis hati dengan COVID-19 (HR = 8,99; 95\% CI: 4,55 - 17,80, $p$ value 0,001) dan Child Pugh kelas $C$ (HR = 5,61; 95\% CI: 2,76-11,40, p value 0,001)) adalah faktor risiko independen yang terkait dengan kelangsungan hidup yang buruk.

Simpulan: Tingkat kelangsungan hidup pasien sirosis hati dengan COVID-19 lebih rendah dibandingkan pasien sirosis hati tanpa COVID-19. Sirosis hati dengan COVID-19 dan Child Pugh kelas C berkaitan dengan kelangsungan hidup yang rendah.

Kata kunci: Coronavirus disease-2019 (COVID-19), sirosis hati, ketahanan hidup

\section{INTRODUCTION}

Coronavirus disease-2019 (COVID-19) is currently causing a global epidemic worldwide. Globally, $105,429,382$ cumulative cases of COVID-19 were reported as 7 February 2021, while the cumulative death of the infected person counts in 2,302,616 deaths. ${ }^{1}$ COVID-19 is still a major public health issue in the world. In Indonesia, since the first confirmed case report in March 2020, the cases of COVID-19 are still increasing with total 1,341,314 confirmed cases of COVID-19 was reported as 2 March 2021. Total of the deaths was reported in 36,325 patients which contribute mortality rate account for $2.71 \%$ and higher than the global estimated. ${ }^{2}$

COVID-19 is a disease caused by infection of the SARS-CoV-2 virus which leads to mortality mainly due to respiratory failure and other organ failure. Transmission of COVID-19 is spread by respiratory droplets from an infected person, direct contact, or contact with a contaminated object. The most common symptoms of
COVID-19 is fever, followed by dry cough and tiredness in mild symptom. ${ }^{3}$ The progression of COVID-19 is more severe in patients with pre-existence morbidities, including chronic liver disease. ${ }^{4}$ Liver cirrhosis (LC) is the end stage of chronic liver disease mainly caused by a viral infection, metabolic fatty liver, or alcohol consumption. ${ }^{5}$ Study found that virus COVID-19 linked with the binding to angiotensin-converting enzyme-2 (ACE-2) receptors which located in hepatocytes and predispose to direct hepatotoxic injury. Liver cirrhosis patient who has immune dysfunction might lead to poorer outcome while infected with COVID-19 and predispose as highrisk population for mortality. ${ }^{6}$

Recently, a few studies showed that liver cirrhosis patients with COVID-19 had a higher risk of mortality rather than liver cirrhosis patients without COVID-19 infection. Bajaj et al found the incidence the deaths of patients with liver cirrhosis with COVID-19 was 30\%, higher than LC without COVID-19, with only $19 \%{ }^{7}$ 
Shalimar et al state that patient liver cirrhosis with COVID-19 have a poor outcome as compared with patient liver cirrhosis alone. Risk factor which associated to in-hospital mortality were international normalized ratio (INR), total bilirubin, creatinine, Child-Pugh score, Model For End-Stage Liver Disease (MELD) score, and requirement of invasive ventilation. ${ }^{8}$ The study of survival COVID-19 in a patient with underlying liver cirrhosis in Indonesia is still limited. The aim of this study is to evaluate the survival of COVID-19 in adult patients with liver cirrhosis.

\section{METHOD}

An observational study in Cipto Mangunkusumo Hospital was conducted. Patients with underlying liver cirrhosis between March 2020-January 2021 with positive confirmation of COVID-19 were enrolled in this study. The inclusion criteria in this study were patient age above 18 years, while the exclusion criteria was patient with HIV/AIDS and malignancy hepatocellular carcinoma (HCC). LC patients without COVID-19 were enrolled as comparison. (Figure 1)

LC was defined as patients with previously diagnosed with liver cirrhosis. In new patients, LC was diagnosed by ultrasonography or liver stiffness measurement $(\geq$ F4). COVID-19 was diagnosed by real-time reversetranscriptase polymerase chain reaction (RT-PCR) oropharyngeal-nasopharyngeal swab. Demographic data, laboratory examination, and liver presentation were collected at the time of hospital admission. Demographic data include sex, age, and etiology. Laboratory examinations include hemoglobin, leukocyte, platelet count, AST, ALT, albumin, bilirubin, prothrombin, INR, creatinine, natrium. Liver presentation includes jaundice, bleeding from esophageal varices, ascites, Child-Pugh, and MELD. Both liver cirrhosis patients with and without COVID-19 were follow up at the time of hospital admission until 30 days outcome. Outcome defined by the death or censored in 30 days after hospital admission.

Data was analyzed using software SPSS version 24. Numerical data was expressed as mean \pm standard deviation for normally data or median (minimummaximum) for abnormally distributed data. $\mathrm{P}$ value for normally data was calculated by student t-test or Man Whitney test for abnormally data. Categorical data was expressed as percentages. P-value for categorical data was calculated by $\chi^{2}$ test. Kaplan Meier was conducted to evaluate the comparison of survival rate in LC patients with and without COVID-19. The power of this study was $80 \%$. Log rank test with $\mathrm{p}$ value under 0.05 was considered as statistical significance. Multivariate Cox Proportional Hazard was conduct to identify the independent risk factors related to survival. The estimation of risk factors was presented as Hazard Ratio (HR) with 95\% interval confidence.

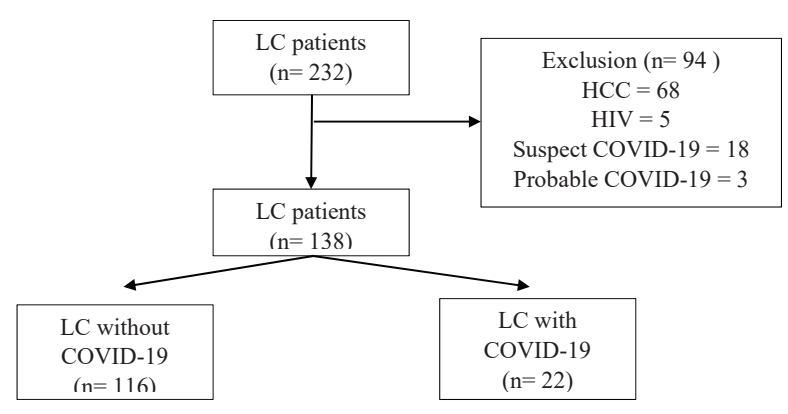

Figure 1. Flow diagram of sample selection

\section{RESULTS}

There were 22 liver cirrhosis patients with COVID-19 and 116 liver cirrhosis patients included in this study. Presentation of gender and age similar both of them. Predominantly males with average age were 57 years $\pm 13,60$ for LC COVID-19 patients and 53 years $\pm 12,75$ for LC without COVID-19 patients. Both in LC COVID-19 and LC without COVID-19, etiology viral was common found than non viral etiology. Distribution of Child-Pugh in LC patients without COVID-19 dominantly with Child-Pugh C (41.4\%), while in population LC with COVID-19 dominantly with Child-Pugh B (40.9\%). (Table 1)

All patients were followed up until 30 days after admission. During 30 days observation period, the overall survival of LC patients was $62.4 \%$. While comparing to sub-analysis patients with COVID-19 infection, the survival rate of LC patients with COVID-19 lower than LC patients without COVID-19 (35.8\% vs. $67.2 \%$, p-value 0.001 ). Median survival of liver cirrhosis patients with COVID-19 was 4 days (95\% CI: 1-8 days), while median survival of LC patients without COVID-19 couldn't be reached since the survival rate of this group above 50\% (Figure 2).

Univariate analysis showed that parameters of the laboratory at hospital admission which associated with non survived patients liver cirrhosis were leukocytosis, elevated liver enzyme transaminase, hypoalbumin, hyperbilirubin, prolong PT/INR, elevated creatinine, and higher MELD score. Sign of decompensation such as jaundice, variceal bleeding, hepatic encephalopathy, ascites, and Child-Pugh class $\mathrm{C}$ were also associated with non survived outcome. In LC patients with COVID-19, the proportion of non survived patients were higher (25.5\%) than survived patients (10.3\%) (Table 2$)$. 
Table 1. Baseline comparison characteristic in patient with liver Cirrhosis

\begin{tabular}{|c|c|c|c|}
\hline Variable & $\begin{array}{l}\text { Cirrhosis } \\
(n=116)\end{array}$ & $\begin{array}{l}\text { Cirrhosis COVID-19 } \\
(\mathrm{n}=22)\end{array}$ & $\mathbf{p}$ \\
\hline \multicolumn{4}{|l|}{ Demographic } \\
\hline Sex male, $\mathrm{n}(\%)$ & $79(68.1 \%)$ & $16(72.7 \%)$ & 0.804 \\
\hline Age & 53 years \pm 12.75 & 57 years \pm 13.60 & 0.136 \\
\hline \multicolumn{4}{|l|}{ Etiology of cirrhosis, n (\%) } \\
\hline Non B Non C & $42(36.2 \%)$ & $10(45.5 \%)$ & 0.468 \\
\hline HBV & 40 (34.5\%) & $4(18.2 \%)$ & \\
\hline $\mathrm{HCV}$ & $33(28.4 \%)$ & $8(36.4 \%)$ & \\
\hline $\mathrm{HBV}$ and $\mathrm{HCV}$ & $1(0.9 \%)$ & $0(0 \%)$ & \\
\hline \multicolumn{4}{|l|}{ Laboratory examination } \\
\hline Hemoglobin, $\mathrm{g} / \mathrm{dL}$ & $8.82 \pm 2.58$ & $9.58 \pm 2.49$ & 0.203 \\
\hline Leukocyte, $10^{9} / \mathrm{L}$ & $9.31 \pm 6.82$ & $10.90 \pm 8.09$ & 0.333 \\
\hline Platelet count, $10^{9} / \mathrm{L}$ & $140.69 \pm 109.95$ & $133.27 \pm 122.98$ & 0.776 \\
\hline AST, U/L & $48(15-2606)$ & $49(6-411)$ & 0.848 \\
\hline $\mathrm{ALT}, \mathrm{U} / \mathrm{L}$ & $32(5-1608)$ & $28(12-143)$ & 0.286 \\
\hline Albumin, g/dL & $2.72 \pm 0.67$ & $2.45 \pm 0.80$ & 0.094 \\
\hline Bilirubin, $\mu \mathrm{mol} / \mathrm{I}$ & $2.13(0.28-42)$ & $3.93(0.62-32.71)$ & 0.207 \\
\hline Prothrombin & $12.85(9.9-120)$ & $14.2(10.8-25.6)$ & 0.050 \\
\hline INR & $1.21(0.90-8.89)$ & $1.42(1.08-2.56)$ & 0.002 \\
\hline Creatinine & $1.05(0.33-9.30)$ & $1.20(0.5-36.5)$ & 0.183 \\
\hline Natrium & $133(108-154)$ & $130(119-147)$ & 0.097 \\
\hline \multicolumn{4}{|l|}{ Liver presentation } \\
\hline Jaundice, $\mathrm{n}(\%)$ & $28(24.1 \%)$ & $8(36.4 \%)$ & 0.351 \\
\hline Bleeding esophageal varices, $\mathrm{n}(\%)$ & $64(55.2 \%)$ & $3(13.6 \%)$ & 0.027 \\
\hline Hepatic encephalopathy, n (\%) & $36(31 \%)$ & $3(13.6 \%)$ & 0.160 \\
\hline \multicolumn{4}{|l|}{ Ascites, n (\%) } \\
\hline Absence & $48(41.4 \%)$ & $14(63.6 \%)$ & 0.121 \\
\hline Mild & $18(15.5 \%)$ & $1(4.5 \%)$ & \\
\hline Massive & $50(43.1 \%)$ & $7(31.8 \%)$ & \\
\hline \multicolumn{4}{|l|}{ Child Pugh, $n(\%)$} \\
\hline A & $27(23.3 \%$ & $5(22.7 \%)$ & 0.872 \\
\hline B & $41(35.3 \%)$ & $9(40.9 \%)$ & \\
\hline C & $48(41.4 \%)$ & $8(36.4 \%)$ & \\
\hline Meld score & $18.82 \pm 8.92$ & $26.24 \pm 10.18$ & 0.001 \\
\hline
\end{tabular}

AST: aspertate aminotransferase, ALT: alanine aminotransferase, INR: international normalised ratio

Table 2. Risk factor of mortality in patient with liver cirrhosis

\begin{tabular}{|c|c|c|c|}
\hline Variable & $\begin{array}{l}\text { Survived } \\
(n=87)\end{array}$ & $\begin{array}{l}\text { Non survived } \\
(n=51)\end{array}$ & $\mathbf{p}$ \\
\hline \multicolumn{4}{|l|}{ Demographic } \\
\hline Sex male, n (\%) & $61(70.1 \%)$ & $34(66.7 \%)$ & 0.746 \\
\hline Age & 51 years \pm 12.81 & 57 years \pm 12.50 & 0.011 \\
\hline \multicolumn{4}{|l|}{ Etiology of cirrhosis, $\mathrm{n}(\%)$} \\
\hline Non B Non C & $31(35.6 \%)$ & $21(41.2 \%)$ & - \\
\hline HBV & $25(28.7 \%)$ & $19(37.3 \%)$ & 0.714 \\
\hline $\mathrm{HCV}$ & 30 (34.5\%) & $11(21.6 \%)$ & 0.243 \\
\hline HBV and HCV & $1(1.1 \%)$ & $0(0 \%)$ & 0.976 \\
\hline \multicolumn{4}{|l|}{ Laboratory examination } \\
\hline Hemoglobin, g/dL & $8.56 \pm 2.73$ & $9.59 \pm 2.15$ & 0.024 \\
\hline Leukocyte, $10^{9} / \mathrm{L}$ & $7.59 \pm 5.46$ & $12.94 \pm 8.11$ & 0.001 \\
\hline Platelet count, $10^{9} / \mathrm{L}$ & $129.98 \pm 95.82$ & $155.77 \pm 134.01$ & 0.191 \\
\hline AST, U/L & $39(6-257)$ & $78(25-2606)$ & 0.001 \\
\hline $\mathrm{ALT}, \mathrm{U} / \mathrm{L}$ & $28(11-422)$ & $42(4.9-1608)$ & 0.001 \\
\hline Albumin, g/dL & $2.94 \pm 0.67$ & $2.25 \pm 0.49$ & 0.001 \\
\hline Bilirubin, $\mu \mathrm{mol} / \mathrm{l}$ & $1.46(0.28-22.45)$ & $5.02(0.38-42)$ & 0.001 \\
\hline Prothrombin & $12.4(9.9-20.40)$ & $14.80(10.80-120)$ & 0.001 \\
\hline INR & $1.21(0.90-1.95)$ & $1.44(0.98-8.89)$ & 0.001 \\
\hline Creatinine & $0.96(0.33-16.20)$ & $1.60(0.40-36.5)$ & 0.001 \\
\hline Natrium & $136(107.7-145)$ & $130(116-154)$ & 0.001 \\
\hline \multicolumn{4}{|l|}{ Liver presentation } \\
\hline Jaundice, n (\%) & $10(11.5 \%)$ & $26(51 \%)$ & 0.001 \\
\hline Bleeding esophageal varices, $\mathrm{n}(\%)$ & $49(56.3 \%)$ & $18(35.3 \%)$ & 0.020 \\
\hline Encephalopathy hepaticum, n (\%) & $9(10.3 \%)$ & $30(58.8 \%)$ & 0.001 \\
\hline \multicolumn{4}{|l|}{ Ascites, $\mathrm{n}(\%)$} \\
\hline Absence & $51(58.6 \%)$ & $11(21.6 \%)$ & - \\
\hline Mild & $18(20.7 \%)$ & $1(2 \%)$ & 0.216 \\
\hline Massive & $18(20.7 \%)$ & $39(76.5 \%)$ & 0.001 \\
\hline \multicolumn{4}{|l|}{ Child Pugh, n (\%) } \\
\hline$A / B$ & $70(80.5 \%)$ & $12(23.5 \%)$ & - \\
\hline $\mathrm{C}$ & 17 (19.5\%) & 39 (76.5\%) & 0.001 \\
\hline Meld score & $15.99 \pm 6.42$ & $26.86 \pm 10.01$ & 0.001 \\
\hline \multicolumn{4}{|l|}{ Covid Infection } \\
\hline Cirrhosis without COVID-19 & $78(89.7 \%)$ & $38(74.5 \%)$ & - \\
\hline Cirrhosis with COVID-19 & $9(10.3 \%)$ & $13(25.5 \%)$ & 0.001 \\
\hline
\end{tabular}

AST: aspertate aminotransferase, ALT: alanine aminotransferase, INR: international normalised ratio 


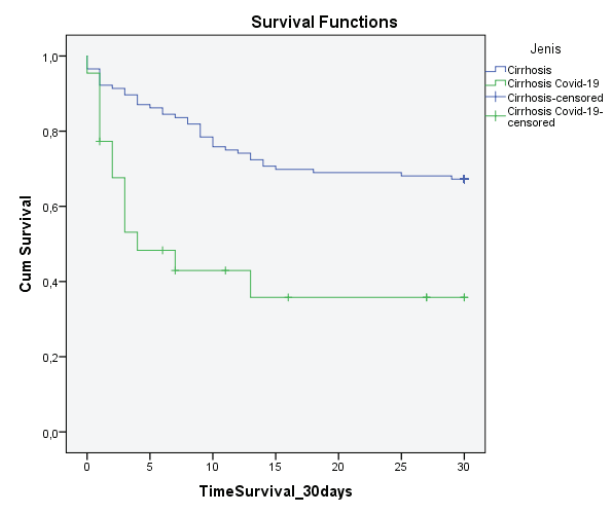

Figure 2. Kaplan Meier survival comparisson LC COVID-19 vs LC without COVID-19

Final model Cox $\mathrm{PH}$ showed that liver cirrhosis with COVID-19 (HR: = 8.99; CI 95\%: 4.55 - 17.80; p-value $0.001)$ and Child-Pugh class $\mathrm{C}(\mathrm{HR}=5.61$; CI 95\%: 2.76 - 11.40; $p$-value 0.001 ) were the independent risk factors associated with poor survival (Table 3 ).

Table 3. Multivariate risk factor of mortality in patient with liver
cirrhosis
\begin{tabular}{lcc}
\hline Variable & HR $(95 \% \mathrm{Cl})$ & $\mathbf{P}$ \\
\hline Child pugh class & & - \\
A/B & 1 & 0.001 \\
C & $5.61(2.76-11.40)$ & - \\
$\begin{array}{l}\text { Comorbidity } \\
\text { Cirrhosis only }\end{array}$ & 1 & - \\
Cirrhosis with COVID-19 & $8.99(4.55-17.80)$ & 0.001 \\
\hline
\end{tabular}

\section{DISCUSSION}

Overall survival of LC patients at 30-days in this study was $62.4 \%$. Survival rate 30 -days of LC patients with COVID-19 lower than LC patients without COVID-19 (35.8\% vs. $67.2 \%$, p value 0.001 ). Survival 30-days from study Iavorane in the setting of cirrhosis patients with infection of COVID-19 was found $66 \%$ with a median of survival was $10(4-13)$ days from diagnosis of COVID-19. When the subjects were divided into sub-group analysis comparing the infection with and without of COVID-19, Iavorane also report that survival 30-days of LC patients related with COVID-19 was poorer than in LC patients with bacterial infection ( $75 \%$ vs. $88 \%$ ). Higher MELD score at admission contribute as factor that predict of survival in those patients. ${ }^{9}$

In this study, 30-days of survival LC patients lower than Iavorane study might explain with the characteristics of baseline at the time of hospital admission. An amount of $40.6 \%$ had an advanced Child-Pugh C, with the complication of liver cirrhosis were variceal bleeding (48.5\%), massive ascites $(41.3 \%)$, hepatic encephalopathy $(28.3 \%)$, and jaundice (26\%). It suggests that the overall of survival liver cirrhosis patients in this study was low due to the higher number of advanced liver cirrhosis and the complication of the liver.

Factors that associated with 30-day survival in this study were patients with infection COVID-19 and sign of liver decompensation. In this study, the infection of COVID-19 was found in twenty-two liver cirrhosis patients. The severity of COVID-19 dominant with severe illness (59\%), followed with moderate illness $(31.8 \%)$, and mild illness $(9.2 \%)$. In those patients, amount of $90.8 \%$ patients had presence pneumonia. Comorbidity of liver cirrhosis patients with COVID-19 was found in nine patients. Multiple comorbidites were observed in four patients. Diabetes mellitus was found in eight patients, hypertension in four patients, liver cancer in two patients, and stroke in one patient.

Grace et al reported the mechanism for mortality COVID-19 in patients with decompensated cirrhosis is related to the binding of angiotensin-converting enzyme 2 (ACE2) which is expressed in the hepatic cell. Expression of ACE2 abundantly in liver parenchymal facilitated the virus entry to the host, upregulated the activity of ACE2, and subsequent to mediated liver injury. ${ }^{10}$ Galiero et al supported data that chronic liver disease upon admission increase the risk of mortality in COVID-19 patients (OR $=5.87$; 95\% CI: 2.41-14.29; p value $<0.001)$, meanwhile multiple comorbidities $>3$ also contribute to increasing the risk mortality of this subject ( $\mathrm{OR}=3.70 ; 95 \% \mathrm{CI}$ : 2.12-6.44, p-value $<0.001) .{ }^{11}$ The role of COVID-19 increase mortality in pre-existence liver disease still not clear. Based on this study, the liver cirrhosis patients with the advance liver disease already characterized by the worse clinical condition at the time of hospital admission, which later contributes to the poor outcome.

In this cohort, liver cirrhosis patients with advanced Child-Pugh $\mathrm{C}$ at the time of admission contributed to poor survival. In this study, patients with either Child-Pugh class A or B survived at 30-days after first hospital admission, while the non survived patients most observed in Child-Pugh Class C. Worse of liver function might have a role in increasing the mortality rate patients with COVID-19 beside the complication of respiratory function. Study Moon et al reported a high mortality rate from COVID-19 infection in patients with pre-existing cirrhosis. The study showed that the case fatality rate from COVID-19 increasing with the stage of liver cirrhosis. Mortality observed in Child-Pugh A-C was $23.9 \%, 43.3 \%$, and $63 \%$, respectively. Child-Pugh $\mathrm{C}$ associated with the risk of mortality COVID-19 patients (OR $=28.07$; CI 95\%: 4.42-178.46; $\mathrm{p}<0.001) .{ }^{12}$ Study Sharin et al 
also reported that patients with decompensated liver cirrhosis were more common getting severe illness from COVID- $19(33.3 \%$ vs. $8 \%, \mathrm{HR}=5.5 ; 95 \% \mathrm{CI}$ : $1.1-44.2 ; \mathrm{p}=0.02$ ) with higher complication and respiratory failure. ${ }^{13}$ Liver cirrhosis is a condition related to dysregulation of the innate immune response and might result to increasing the severe progression of acute respiratory syndrome coronavirus 2 (SARS-CoV-2) due to liver injury. The biological mechanism which possible to increase liver damage in COVID-19 patients were direct cytotoxicity due to viral replication, immune-mediated inflammation due to intense cytokines storm, drug-induced liver injury, and reactivation of pre-existing hepatic disease. ${ }^{14}$

Liver is one of organ that affected by COVID-19. In clinical practice when dealing with COVID-19 patients with cirrhosis, clinicians must be more alert, both to the worsening of COVID-19 condition and worsening of liver function, especially if the COVID-19 patient has a condition with decompensated LC. If a patient with decompensated LC is infected with COVID-19, it can worsen the liver function and lead to worse survival outcome. COVID-19 patient with elevated liver enzyme transaminase and clinical presentation of decompensated LC need more attention to be monitored.

\section{CONCLUSION}

This study support that patient COVID-19 with decompensated liver cirrhosis is associated with poor survival. The survival rate of liver cirrhosis patients with COVID-19 lower than liver cirrhosis patients without COVID-19. Liver cirrhosis patients with COVID-19 and decompensated of liver cirrhosis could be a prognostic factor for poor survival in this study.

\section{REFERENCES}

1. WHO. Weekly epidemiological update - 9 February 2021 [serial online] [cited 2021 March 2]. Available from: https:// www.who.int/publications $/ \mathrm{m} /$ item/weekly-epidemiologicalupdate---9-february-2021.

2. WHO. Indonesia Situation [serial online] [cited $2021 \mathrm{March}$ 2]. Available from: https://COVID19.who.int/region/searo/ country/id.

3. Lai CC, Shih TP, Ko WC, Tang HJ, Hsueh PR. Severe acute respiratory syndrome coronavirus 2 (SARS-CoV-2) and coronavirus disease-2019 (COVID-19): The epidemic and the challenges. Int J Antimicrob Agents 2020;55:105924.

4. Praveen S, Ashish K, Anikhindi SA, Naresh B, Vikas S, Khare $\mathrm{S}$, et al. Effect of COVID-19 on pre-existing liver disease: What Hepatologist should know? J Clin Ex Hepatol 2020;12:1.
5. Schuppan D, Afdhal NH. Liver cirrhosis. Lancet 2008;371:838-51.

6. COVID-19 and liver disease: An update Luis Téllez, Rosa María Martín Mateos Servicio de Gastroenterología y Hepatología, Hospital Universitario Ramón y Cajal, Madrid, Spain

7. Bajaj JS, Garcia-Tsao, G, Biggins SW, et al. Comparison of mortality risk in patients with cirrhosis and COVID-19 compared with patients with cirrhosis alone and COVID-19 alone: multicentre matched cohort. Gut 2020;382:531-6..

8. Shalimar, Elhence A, Vaishnav M, Kumar R, Pathak P, Soni $\mathrm{KD}$, et al. Poor outcomes in patients with cirrhosis and Corona Virus Disease-19. Indian J Gastroenterol 2020;39;285-91.

9. Iavarone M, D'Ambrosio R, Soria A, Triolo M, Pugliese N, Del Poggio P, et al. High rates of 30-day mortality in patients with cirrhosis and COVID-19. J Hepatol 2020;73:1063-71.

10. Grace JA, Casey S, Burrell LM, Angus PW. Proposed mechanism for increased COVID-19 mortality in patients with decompensated cirrhosis. Hepatol Int 2020;14:884-5.

11. Galiero R, Pafundi PC, Simeon V, Rinaldi L, Perrella A, Vetrano E, et al. Impact of chronic liver disease upon admission on COVID-19 in-hospital mortality: Findings from COVOCA study. PLoS One 2020;15:e0243700.

12. Moon AM, Webb GJ, Aloman C, Armstrong MJ, Cargill T, Dhanasekaran R, et al. High mortality rates for SARS-CoV-2 infection in patients with pre-existing chronic liver disease and cirrhosis: Preliminary results from an international registry. J Hepatol 2020;73:705-8.

13. Sarin SK, Choudhury A, Lau GK, Zheng MH, Ji D, AbdElsalam S, et al. Pre-existing liver disease is associated with poor outcome in patients with SARS CoV2 infection; The APCOLIS Study (APASL COVID-19 Liver Injury Spectrum Study). Hepatology Int 2020;14:690-700.

14. Ali N. Relationship Between COVID-19 infection and liver injury: a review of recent data. Front Med (Lausanne) 2020;7:458. 